\title{
Polymorphism of C3 complement in association with myocardial infarction in a sample of central Tunisia
}

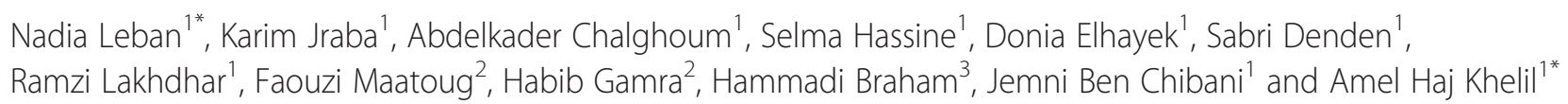

\begin{abstract}
Background: Myocardial infarction (MI) is a major clinical problem because of its large contribution to mortality. The genetic bases of this disease have been widely studied in recent years to find a clear association with some genetic markers that increase the risk of its occurrence. In the present investigation, the correlation between $\mathrm{Ml}$ and the C3 complement polymorphism was analyzed using a case-control study.

Methods: Our study ported on one hundred seventy survived myocardial infarction patients and ninety five healthy controls. The C3 allele identification was investigated using the amplification refractory mutation system PCR to determine the C3*S and the C3*F alleles of the C3 polymorphism.

Results: Frequencies of $\mathrm{C}^{*} \mathrm{~S}$ and $\mathrm{C} 3^{*} \mathrm{~F}$ in patients are 0.59 and 0.41 respectively. Fisher test results showed a significant increase of $\mathrm{C} 3^{*} \mathrm{~F}$ allele in the sample of patients (0.41; odds ratio: 2.616; C.I [1.738-3.938]) compared to controls (0.21; odds ratio: $0.382 ; 95 \% \mathrm{Cl}[0.254-0.575]), p=2.742 \times 10^{-6}$.
\end{abstract}

Conclusion: A strong positive correlation was found between C3 polymorphism and Ml estimating that the risk of myocardial infarction is significantly increased among patients with C $3^{*} \mathrm{~F}$ allele of this polymorphism.

Virtual Slides: The virtual slide(s) for this article can be found here: http://www.diagnosticpathology.diagnomx.eu/ vs/1190484203893646

Keywords: Myocardial infarction, C3 complement, Polymorphism, Allele frequency, Association

\section{Introduction}

Myocardial infarction (MI) is the rapid development of myocardial necrosis caused by a critical imbalance between oxygen supply and demand of the myocardium. This usually results from plaque rupture with thrombus formation in a coronary vessel, resulting in an acute reduction of blood supply to a portion of the myocardium. Important risk factors are: previous cardiovascular disease, older age, tobacco smoking, high blood levels of certain lipids (triglycerides, low-density lipoprotein) and low levels of high density lipoprotein (HDL), diabetes, high blood pressure, obesity, chronic kidney disease, heart failure, excessive alcohol consumption, abuse of

\footnotetext{
*Correspondence: lebannadia@yahoo.fr; hajhelil@yahoo.fr

${ }^{1}$ Biochemistry and Molecular Biology Laboratory, Faculty of Pharmacy, Street Avicenne, 5019 Monastir, Tunisia

Full list of author information is available at the end of the article
}

certain drugs, Thiamine deficiency (beriberi), and chronic high stress levels [1-3]. MI is a major clinical problem because of its large contribution to mortality. According to the World Health Organization, heart attacks are among the most important cause of death for both men and women all over the world.

In addition to these common risk factors, studies have shown the importance of genetic factors. The genetic bases of this disease have been widely studied to find a clear association between the MI and some genetic markers that increase the risk of its occurrence (Table 1). Among the studied genetic markers we find the $\mathrm{C} 3 \mathrm{com}$ ponent of the complement. The C3 protein is composed of 1663 amino acids. The C3 gene is localized in 19 p13.3-2 and contains 41 exons spread over $41 \mathrm{~Kb}$. The polymorphism of the $\mathrm{C} 3$ gene is under the control of codominant autosomal alleles. The two most common 
Table 1 List of genetic markers analyzed for the association with myocardial infarction

\begin{tabular}{cccc}
\hline Gene & Polymorphism & Association & References \\
\hline C3 complement & C3*S & - & {$[5,6]$} \\
\cline { 2 - 3 } & C3*F & + & {$[7]$} \\
\hline CYP2J2 & G50T & - & {$[8]$} \\
\hline VEGF & -634 & + & {$[9]$} \\
\hline COX-2 & PTGS2 & + & {$[10]$} \\
\hline PGIS & CYP8A1 & + & \\
\hline IL-18 promoter & $-607 C / A$ & + & {$[11]$} \\
\cline { 2 - 3 } & -137 G/C & - & \\
\hline PSMA6 & $-8 C>G$ & + & {$[12]$} \\
\hline MTAP & 21807754 G/A & + & {$[13]$} \\
\hline CDKN2B & $21993223 \mathrm{G}>\mathrm{A}$ & + & \\
\cline { 2 - 3 } & $21993367 \mathrm{~A} / \mathrm{G}$ & + & {$[14]$} \\
\hline Fas promoter & $-670 \mathrm{G} / \mathrm{A}$ & + & {$[16]$} \\
\hline Serotonin transporter & $5-H T T L P R(L / S)$ & + & {$[17]$} \\
\hline ACE & Insertion/Deletion & + & {$[18]$} \\
\hline Near INSIG2 & $7543947 \mathrm{C}>\mathrm{G}$ & - &
\end{tabular}

(+): positive; (-): negative.

allotypes are $\mathrm{C}^{*} \mathrm{~S}$ (S for slow) and $\mathrm{C} 3{ }^{*} \mathrm{~F}$ (F for fast). The C3 polymorphism (R102G) consists on G to C substitution at position 364 in exon 3 leading to a change of Arginine in $\mathrm{C}^{*} \mathrm{~S}$ to Glycine in $\mathrm{C} 3 * \mathrm{~F}[4]$.

The C3 complement component polymorphism was often used as a powerful marker for genetic studies of populations [19], since it is biallelic and codominant single nucleotide polymorphism, the complement system has a critical role in both the innate and the adaptive immune responses [20]. In humans, C3*F (C3102G) has been associated with autoimmune diseases [21,22]. Few researches are carried out in the literature on the correlation between $\mathrm{C} 3$ polymorphism and MI. This relationship has been studied most often on the serum level. Previous studies showed that the C3 serum protein is correlated with a set of risk factors for MI [23]. Considering the pathophysiological data, it seems that the carriers of the $\mathrm{C}^{*} \mathrm{~F}$ allele are able to control inflammatory diseases to a lesser extent than non-carriers may do. Therefore, in the case of $\mathrm{C} 3{ }^{*} \mathrm{~F}$ carriers, there may be a higher likelihood of inflammation within the vulnerable plaques that may facilitate their rupture [24] and the consequential development of myocardial infarction. The more common $\mathrm{C}^{*} \mathrm{~S}$ allele may have an effect of opposite direction that protects against the development of MI [7]. C3 could be considered as a factor screening primary prevention of myocardial infarction [25]. In this context, we are interested to analyze the association between the single-nucleotide polymorphism in the $\mathrm{C} 3$ complement component gene and the risk of developing MI in the Tunisian population. To achieve this purpose, we carried out a case control study. This research falls within the framework of improving the strategy for prevention of this disease. By identifying the genetic markers that may increase the risk of its occurrence, it would be possible to carry out the interventions needed to reduce the possibility of future events.

\section{Methods}

\section{Study populations}

This work was performed on 170 blood samples of patients aged between 44 and 83 years (mean age: $65,48 \pm 10,91$ years) who have survived to myocardial infarction followed in the cardiology departments at the University Hospitals of Sousse, Monastir and Mahdia. For blood collect, we have obtained approval from the Hospital authority and the ethics committee after consent of patients. For each patients, we reported the body mass index, the triglycerides, HDL-c, LDL-c and cholesterol concentrations, the risk factors (mainly smoking), and the history of the disease (such as diabetes, arterial hypertension, dyslipidemia,...). Ninety-five healthy Tunisian adult blood donors were included in the study as control sample.

\section{Genetic analysis}

DNA extraction was performed on $5 \mathrm{ml}$ of peripheralblood samples collected on EDTA from patients and controls using the standard phenol/chloroform method. Amplification Refractory mutation System (ARMS) PCR [26] was used for the two groups to determine the $C 3 * S$ and $\mathrm{C} 3^{*} \mathrm{~F}$ alleles. The technique requires that the terminal 3'-nucleotide only of a PCR primer be allele specific. Thus the primer is synthesized in two forms. The normal form ( $\mathrm{C}^{*} \mathrm{~S}$ primer) is refractory to PCR on mutant template DNA $\left(\mathrm{C}^{*} \mathrm{~F}\right)$ and vice versa. Introducing additional deliberate mismatches near the 3 ' end of appropriate primers does not allow non specific amplification to proceed, that's why we preferred this method

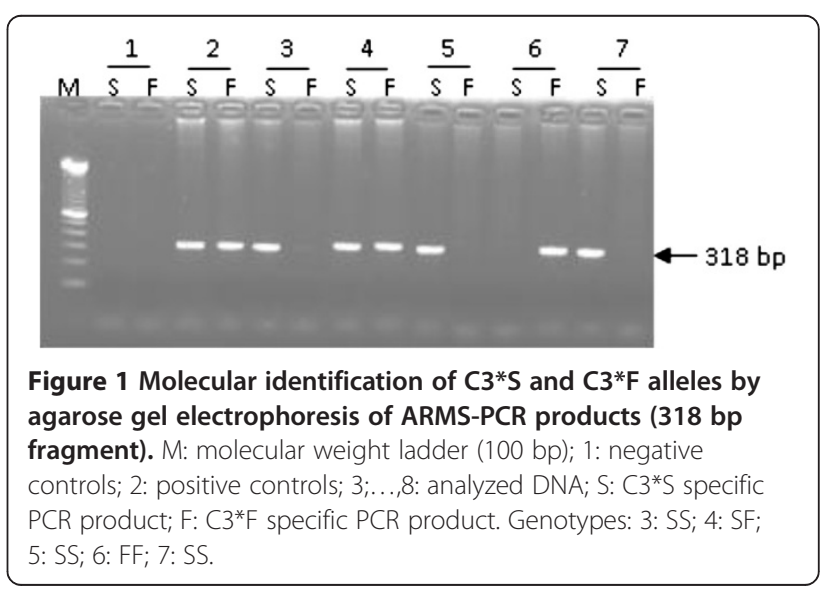


Table 2 Association test between C3 polymorphism and myocardial infarction by comparing genotype and allele frequencies of $\mathrm{C} 3 * \mathrm{~S}$ and $\mathrm{C} 3 * \mathrm{~F}$ in patients and controls

\begin{tabular}{|c|c|c|c|c|c|}
\hline \multirow{2}{*}{ Number } & & \multirow{2}{*}{$\begin{array}{c}\text { Controls } \\
95\end{array}$} & \multirow{2}{*}{$\begin{array}{l}\text { MI patients } \\
170\end{array}$} & \multicolumn{2}{|c|}{ Fisher test } \\
\hline & & & & & \\
\hline \multirow[t]{4}{*}{ Allelic Frequencies } & $\mathrm{C} 3 * \mathrm{~S}$ & 0.79 & 0.59 & Odds ratio $=0.382$ & $p=2.742 \times 10^{-6}$ \\
\hline & & & & C.I. $=[0.254-0.575]$ & \\
\hline & $\mathrm{C} 3^{*} \mathrm{~F}$ & 0.21 & 0.41 & Odds ratio $=2.616$ & \\
\hline & & & & C.I. $=[1.738-3.938]$ & \\
\hline
\end{tabular}

Cl: confidence interval, Ml: myocardial infarction.

which seems more convenient for genotyping than enzymatic digestion which requires two reactions to be performed.

In the ARMS reaction, three primes were used: one common reverse primer (5'-TGTTGACCATGACCGTC CGGCCCACGGTA-3') and two forward specific primers (5' -CCAACAGGGAGTTCAAGTCAAAAGGTGG-3' for $\mathrm{C}^{*} \mathrm{~S}$ and $5^{\prime}$-CCAACAGGGAGTTCAAGTCAGÄAAAG GTGC-3' for $\mathrm{C}^{*} \mathrm{~F}$ ). For each DNA, the amplification is performed twice on a final volume of $25 \mu \mathrm{l}$ containing $100 \mathrm{ng}$ of DNA, $0.6 \mu \mathrm{M}$ of each primer, $3 \mathrm{mM}$ of $\mathrm{MgCl}_{2}$, $0.32 \mathrm{mM}$ of each $\mathrm{dNTP}$ and $1.5 \mathrm{U}$ of Taq polymerase (Promega). The reaction is performed on an Appligene Oncor thermocycler under the following conditions: $2 \mathrm{~min}$ at $94^{\circ} \mathrm{C}, 33$ cycles of $30 \mathrm{~s}$ at $94^{\circ} \mathrm{C}, 1 \mathrm{~min}$ at $50^{\circ} \mathrm{C}$, $1 \mathrm{~min}$ at $72^{\circ} \mathrm{C}$ and finally, one cycle of $10 \mathrm{~min}$ at $72^{\circ} \mathrm{C}$. PCR products were revealed on $2 \%$ agarose gel electrophoresis and visualized under UV light after ethidium bromide staining. Genotypes are determined for all individuals and frequencies are calculated for the two alleles.

\section{Statistical analysis}

Allele frequencies are compared in the samples of MI patients and controls using Epi info 6 software (Fisher test).

\section{Results}

The ARMS PCR allowed to determine the different genotypes since homozygous DNA for $\mathrm{C} 3 \% \mathrm{~F}$ and $\mathrm{C} 3 \% \mathrm{~S}$ alleles are amplified only in presence of $\mathrm{F}$ or $\mathrm{S}$ specific primers respectively whereas heterozygous DNA are amplified in presence of both primers (Figure 1). The genotyping of MI samples allowed calculating the allelic frequencies of C3 under the hypothesis of HardyWeinberg equilibrium. Results for the equilibrium test showed that the difference between observed and expected frequencies is not significant $\left(X^{2}=1.286<3.84\right)$.

The genotype and alleles frequencies of $C 3 * S$ and $\mathrm{C}^{*} \mathrm{~F}$ found in this study are summarized in Table 2. These values are compared with those of controls.

$\mathrm{C}^{*} \mathrm{~S}$ allele frequency is higher than $\mathrm{C}^{*} \mathrm{~F}$ in the two populations (controls and patients). For the $\mathrm{C} 3 * \mathrm{~F}$ allele, the frequency found in patients $(0.41)$ is 2 times higher than that found in controls $(0.21)$. Thus, the $\mathrm{C} 3 * \mathrm{~S}$ allele frequency is reduced (0.59) in the sample of patients compared to that of controls (0.79).

Fisher test results showed a significant increase of $\mathrm{C}^{*} \mathrm{~F}$ allele in the sample of patients $\left(\mathrm{p}=2.742 \times 10^{-6}\right)$. Therefore, it is estimated that the risk of myocardial infarction is significantly increased among patients with the $\mathrm{C} 3{ }^{*} \mathrm{~F}$ polymorphism (Table 2 ).

\section{Discussion}

Our results about the allelic frequencies of the donors sample are compared to those of previous study in which sera from 95 healthy donors (representative of the Tunisian general population) are phenotyped using agarose gel electrophoresis [27]. The similarity observed between $\mathrm{C}^{*} \mathrm{~S}$ and $\mathrm{C} 3$ * $\mathrm{F}$ frequencies in the two studies strengthens our findings.

Our results showed a strong association between $\mathrm{C} 3{ }^{*} \mathrm{~F}$ polymorphism and the risk of the MI since the probability $\mathrm{P}$ is $2.742 \times 10^{-6}(<0.05)$. Based on these results, homozygous for the $\mathrm{C} 3 * \mathrm{~S}$ allele are more protected against the occurrence of myocardial infarction. In the contrary, this risk is highly increased for homozygous $\mathrm{C}{ }^{*} \mathrm{~F}$ individuals.

Table 3 Association of C3 polymorphism with various cardiopathies

\begin{tabular}{|c|c|c|c|c|c|c|c|}
\hline \multirow[t]{3}{*}{ Disease } & \multicolumn{6}{|c|}{ Allele frequencies } & \multirow[t]{3}{*}{ References } \\
\hline & \multicolumn{3}{|c|}{ Controls } & \multicolumn{3}{|c|}{ Patients } & \\
\hline & $\mathbf{N}$ & C3*S & $\mathrm{C} 3{ }^{*} \mathrm{~F}$ & $\mathrm{~N}^{\prime}$ & C3*S & $\mathrm{C} 3 * \mathrm{~F}$ & \\
\hline Cardiomyopathy & 100 & 0.840 & 0.160 & 57 & 0.771 & $0.228^{*}$ & [33] \\
\hline Coronary heart disease (CHD) & 523 & 0.832 & 0.168 & 171 & 0.827 & $0.213^{*}$ & {$[7]$} \\
\hline Atherosclerosis & 62 & 0.882 & 0.118 & 139 & 0.532 & $0.468^{*}$ & [32] \\
\hline
\end{tabular}

$\mathrm{N}$ and $\mathrm{N}^{\prime}$ : number of individuals, *: significant difference $(\mathrm{P}<0.05)$. 
In the literature, only few associations between the C3 component polymorphism and myocardial infarction have been analyzed. In one of them, carried out on the territory of Delhi (India), the difference between MI cases and controls was found to be statistically nonsignificant indicating that, in this Indian population, the C3 marker is not associated with the risk of myocardial infarction [6]. Another study was a C3 phenotype serum investigation in patients with heart infarct. Despite differences in the percentage distribution of various phenotypes between the patients' sera and those of controls, no significant association could be established [5]. However, a positive correlation was found in the Hungarian population in which the $\mathrm{C} 3^{*} \mathrm{~F}$ allele may be associated with an increased risk of developing myocardial infarction in coronary heart disease patients [7].

Several associations of the C3 polymorphism with other diseases have been reported (Table 3). Atherosclerosis is an inflammatory disease and the complement system plays an important role in its process. Previous study provides further evidence of a positive association of the $\mathrm{C}^{*} \mathrm{~F}$ allele with atherosclerosis, and it is concluded that this allele in a hypertensive patient might accelerate the atherosclerotic process, with subsequent premature development of vascular complications [28]. Significantly increased frequency of $\mathrm{C}^{*} \mathrm{~F}$ was observed in patients with the cardiomyopatic form of Chagas disease compared to those presenting the asymptomatic indetermined form and with the healthy controls. These results present the $\mathrm{C} 3 * \mathrm{~F}$ allele as a susceptible marker for the progression of the cardiomyopatic form of Chagas disease [29]. Further investigations showed a significant risk of lung cancer among men of the C3 SF/FF genotypes compared to the SS genotype [30]. Finally, many studies have demonstrated an association between the $\mathrm{C} 3 * \mathrm{~F}$ allele and the presence of age-related macular degeneration (AMD) [31-33].

\section{How explain the implication of the variant C3F in the diseases development?}

Number of studies suggests that functional differences exist between $\mathrm{C} 3$ complement allotypes $\mathrm{F}$ and $\mathrm{S}$ in the pathogenesis of MI and other diseases with a higher risk found in individuals with allotype F. Hemolytic activity is slower for $\mathrm{C} 3 * \mathrm{~F}$ than for $\mathrm{C} 3 * \mathrm{~S}$ products [34]. It has been shown that erythrocytes encoded with $\mathrm{C} 3 * \mathrm{~F}$ are surrounded by much more bearing monocytes than C3*S [35].

The C3F variant bound Factor $\mathrm{H}$ Complement (CFH) less than C3S, causing decreased Factor I Complement cofactor activity, and enhanced C3 alternative pathway amplification. By combining risk and protective alternative pathway variants (activators and regulators), it has been shown that $\mathrm{C} 3, \mathrm{CFH}$, and Factor $\mathrm{B}$ variants collaborate to set levels of alternative pathway of systemic complement activity in plasma, thereby influencing risk in complement-dependent diseases [36]. However, no difference between $\mathrm{C} 3^{*} \mathrm{~F}$ and $\mathrm{C} 3^{*} \mathrm{~S}$ forms in their binding to complement receptors types 1,2 and 3 was shown [37]. In addition, in vitro experimental evidence showing functional differences between the two forms of $\mathrm{C} 3$ is not conclusive [31].

\section{Conclusion}

In conclusion, our study showed a strong association between the $\mathrm{C} 3 * \mathrm{~F}$ variant and $\mathrm{MI},(0.41$ versus 0.21 with $\left.\mathrm{p}=2.742 \times 10^{-6}\right)$. C $3 * \mathrm{~F}$ appears to have a causal role in increasing the risk of occurrence of this disease. These results add to our understanding of the genetic factors of myocardial infarction and provide evidence that the $\mathrm{C} 3$ complement component may be a predisposing factor for this common disease. The determination of C3 polymorphism may help in the identification of patients at risk for developing MI.

\section{Competing interests}

The authors declare that they have no competing interests.

\section{Authors' contributions}

All authors read and approved the final manuscript.

\section{Acknowledgment}

We thank Professor Gérard Lefranc from the University Montpellier 2 for his help and for providing some reagents for the molecular analysis.

\section{Author details}

${ }^{1}$ Biochemistry and Molecular Biology Laboratory, Faculty of Pharmacy, Street Avicenne, 5019 Monastir, Tunisia. ${ }^{2}$ Cardiology Department, Fattouma Bourguiba Universitary Hospital, Monastir, Tunisia. ${ }^{3}$ Biochemistry and Blood Bank Department, Universitary Hospital Taher Sfar, Mahdia, Tunisia.

Received: 14 January 2013 Accepted: 4 March 2013

Published: 13 June 2013

\section{References}

1. Pearte CA, Furberg CD, O'Meara ES, Psaty BM, Kuller L, Powe NR, Manolio T: Characteristics and baseline clinical predictors of future fatal versus nonfatal coronary heart disease events in older adults: the Cardiovascular Health Study. Circ 2006, 113(18):2177-2185.

2. Bax L, Algra A, Mali WP, Edlinger M, Beutler JJ, van der Graaf Y: Renal function as a risk indicator for cardiovascular events in 3216 patients with manifest arterial disease. Atherosclerosis 2008, 200:184.

3. Bello S, Neri M, Riezzo I, Othman MS, Turillazzi E, Fineschi V: Cardiac beriberi: morphological findings in two fatal cases. Diagn Pathol 2011, 6:8.

4. Botto M, Fong KY, So AK, Koch C, Walport MJ: Molecular basis of polymorphisms f human complement component C3. J Exp Med 1990, 172:1011-1017. et.

5. Agarwal DP, Srivastava LM, Benkmann HG, Goedde HW: Studies on the polymorphism of C3, Tf and Bg in Down's syndrome and other diseases. Humangenetik 1975, 29(1):23-28.

6. Golabi P, Kshatriya GK, Kapoor AK: Association of genetic markers with coronary heart disease (myocardial infarction)-a case-control study. J Indian Med Assoc 1999, 97(1):6-7.

7. Császár A, Duba J, Melegh B, Kramer J, Szalai C, Prohászka Z, Karádi I, Kovács $M$, Méhes $K$, Romics L, Füst G: Increased frequency of the $C 3^{*} F$ allele and the Leiden mutation of coagulation factor $\mathrm{V}$ in patients with severe coronary heart disease who survived myocardial infarction. Exp Clin Immunogenet 2001, 18(4):206-212. 
8. Börgel J, Bulut D, Hanefeld C, Neubauer H, Mügge A, Epplen JT, HollandLetz T, Spiecker M: The CYP2J2 G-50 T polymorphism and myocardial infarction in patients with cardiovascular risk profile. BMC CardiovasC Disord 2008, 8:41.

9. Douvaras P, Antonatos DG, Kekou K, Patsilinakos S, Chouliaras G, Christou A, Andrikou A, Kanavakis E: Association of VEGF gene polymorphisms with the development of heart failure in patients after myocardial infarction. Cardiology 2009, 114(1):11-18.

10. Xie X, Ma YT, Fu ZY, Yang YN, Ma X, Chen BD, Wang YH, Liu F: Association of polymorphisms of PTGS2 and CYP8A1 with myocardial infarction. Clin Chem Lab Med 2009, 47(3):347-352.

11. Pei F, Han Y, Zhang X, Yan C, Huang M, Huang L, Kang J: Association of interleukin-18 gene promoter polymorphisms with risk of acute myocardial infarction in northern Chinese Han population. Clin Chem Lab Med 2009, 47(5):523-529.

12. Liu X, Wang X, Shen Y, Wu L, Ruan X, Lindpaintner K, Yusuf S, Engert JC, Anand S, Tan X, Liu L: The functional variant rs1048990 in PSMA6 is associated with susceptibility to myocardial infarction in a Chinese population. Atherosclerosis 2009, 206(1):199-203.

13. Yang XC, Zhang Q, Chen ML, Li Q, Yang ZS, Li L, Cao FF, Chen XD, Liu WJ, Jin L, Wang XF: MTAP and CDKN2B genes are associated with myocardial infarction in Chinese Hans. Clin Biochem 2009, 42(10-11):1071-5.

14. Hanasaki H, Takemura Y, Fukuo K, Ohishi M, Onishi M, Yasuda O, Katsuya T, Awata N, Kato N, Ogihara T, Rakugi H: Fas promoter region gene polymorphism is associated with an increased risk for myocardial infarction. Hypertens Res 2009, 32(4):261-264.

15. Xia DS, Guo QY, Liu YQ, Li C, Zhang F, Wei MX: Association of serotonin transporter gene linked polymorphic region polymorphism with early onset myocardial infarction and platelet membrane glycoprotein lb. Zhonghua Yi Xue Yi Chuan Xue Za Zhi 2009, 26(1):31-34.

16. Oztürk O, Oztürk U: Relation between angiotensin-converting enzyme I/D gene polymorphism and pulse pressure in patients with a first anterior acute myocardial infarction. Anadolu Kardiyol Derg 2009, 9(1):9-14.

17. Wiedmann S, Neureuther K, Stark K, Reinhard W, Kallmünzer B, Baessler A, Fischer M, Linsel-Nitschke P, Erdmann J, Schunkert H, Hengstenberg C: Lack of Association Between a Common Polymorphism Near the INSIG2 Gene and BMI, Myocardial Infarction, and Cardiovascular Risk Factors. Obesity (Silver Spring) 2009, 17(7):1390-5.

18. Zhang $X$, Han $Y$, Kang J, Yan C: A monocyte chemoattractant protein-1 gene polymorphism is not associated with coronary artery disease in a Han Chinese population. Clin Chim Acta 2009, 403(1-2):241-243.

19. Davrinche C, Rivat C: Polymorphism of the third component of human complement. Rev Fr Transfus Immuno hematol 1982, 5(2):199-213.

20. Bickerstaff MCM, Botto M, Hutchinson WL, Herbert J: Tennent GA et Bybee A: Serum amyloid $\mathrm{P}$ component controls chromatin degradation and prevents antinuclear autoimmunity. Nat Med 1999, 5:694-697.

21. Puttick AH, Briggs DC, Welsh Kl, Williamson EA, Jacoby RK, Jones VE: Genes associated with rheumatoid arthritis and mild inflammatory arthritis. Association of HLA with complement C3 and immunoglobulin $\mathrm{Gm}$ allotypes. Ann Rheum Dis 1990, 49:225-8.

22. Persson U, Truedsson L, Westman KWA, Segelmark M: C3 and C4 allotypes in anti-neutrophil cytoplasmic autoqntibody (ANCA)-positive vasculitis. Clin Exp Immunol 1999, 116:379-382.

23. Muscari A, Massarelli G, Bastagli L, Poggiopollini G, Tomassetti V, Volta U, Puddu GM, Puddu P: Relationship between serum C3 levels and traditional risk factors for myocardial infarction. Acta Cardiol 1998, 53(6):345-354

24. Kullo IJ, Edwards WD, Schwartz RS: Vulnerable plaque: Pathobiology and clinical implications. Ann Intern Med 1998, 129:1050-1060.

25. Muscari A, Massarelli G, Puddu GM, Sangiorgi Z, Dormi A, Bagnoli M, Gaddi A, Puddu P: Serum C3 as a screening factor in the primary prevention of myocardial infarct. Cardiologia 1995, 40(7):507-514.

26. Newton CR, Graham A, Heptinstall LE, Powell SJ, Summers C, Kalshekerl N, Smith JC, Markham AF: Analysis of any point mutation in DNA. The ampliflcation refractory mutation system (ARMS). Nucleic Acids Res 1989, 17(7):2503-2516.

27. Chibani J, Lefranc G, Constans J: Serum protein polymorphism among Tunisian Berbers: Haptoglobulin, transferrin and group specific component subtypes C3 and BF types. Ann human Biol 1985, 12:449-462.

28. Kristensen BP, Petersen GB: Association between coronary heart disease and the C3F-gene in essential hypertension. Circulation 1978, 58(4):622-625
29. Messias-Reason IJ, Urbanetz L, Pereira da Cunha C: Complement C3 F and BF S allotypes are risk factors for Chagas disease cardiomyopathy. Tissue Antigens 2003, 62(4):308-312.

30. Suadicani P, Hein HO, Finn G: Complement C3 genotype variants and risk of lung cancer mortality. ISRN Pulmonology 2011. doi:10.5402/2011/423571.

31. Yates JRW, Sepp T, Matharu BK, Khan JC, Thurlby DA, Shahid H, Clayton DG, Hayward C, Morgan J, Wright AF, Armbrecht AM, Dhillon B, Deary IJ, Redmond E, Bird AC, Moore AT: Complement C3 variant and the risk of age-related macular degeneration. J Med 2007, 357:553-561.

32. Despriet DD, van Duijn CM, Oostra BA, Uitterlinden AG, Hofman A, Wright $A F$, ten Brink JB, Bakker A, de Jong PT, Vingerling JR, Bergen AA, Klaver CC: Complement component C3 and risk of Age-Related Macular Degeneration. Ophtalmology 2009, 116(3):474-480.

33. Park KH, Fridley BL, Ryu E, Tosakulwong N, Edwards AO: Complement Component 3 (C3) Haplotypes and Risk of Advanced Age-Related Macular Degeneration. Invest Ophthalmol Vis Sci 2009, 50(7):3386-93.

34. Welch TR, Beischel $L$, Kleesattel A: Functional consequences of the genetic polymorphism of the third component of complement. J Pediatr 1990, 116(Suppl):S92-S97.

35. Arvilommi H: Capacity of complement C3 phenotypes to bind on to mononuclear cells in man. Nature 1974, 251:740-741.

36. Heurich M, Martínez-Barricarte R, Francis NJ, Roberts DL: Rodríguez de Cordoba S, Morgan BP and Harris CL: Common polymorphisms in C3, factor $\mathrm{B}$, and factor $\mathrm{H}$ collaborate to determine systemic complement activity and disease risk. PNAS 2011, 108(21):8761-8766.

37. Bartók I, Walport MJ: Comparison of the binding of C3S and C3F to complement receptors types 1, 2 and 3. J Immunol 1995, 154:5367-5375.

doi:10.1186/1746-1596-8-93

Cite this article as: Leban et al:: Polymorphism of C3 complement in association with myocardial infarction in a sample of central Tunisia. Diagnostic Pathology 2013 8:93.

\section{Submit your next manuscript to BioMed Central and take full advantage of:}

- Convenient online submission

- Thorough peer review

- No space constraints or color figure charges

- Immediate publication on acceptance

- Inclusion in PubMed, CAS, Scopus and Google Scholar

- Research which is freely available for redistribution 